\title{
Budgeting And Budgetary Control Practices in Timber industries in Ghana: A Case of Logs and Lumber Limited
}

\author{
*Emmanuel Adjei Frimpong , Francis Ameyaw, Eugene Osei-Bonsu \\ Koforidua Technical University, Koforidua, Ghana, Faculty of Business and Management Studies \\ *emaadjei@ktu.edu.gh
}

\begin{abstract}
The study was undertaken to assess how companies use the activity of budgeting and budgetary control in their management process to achieve their desired results. Logs \& Lumber Limited, a timber company in Kumasi, Ghana was studied. Convenient sampling method was used to select the respondents.. The sample was made up of 17 staff members of the company. The primary data were gathered through questionnaires and structured interview. The secondary data were budget reports and budget manual of the company from 2011-2015. The data obtained from the study were processed using the Stastical Package Software System (SPSS) version 16.0 to assess differences in the results. $100 \%$ of the respondents strongly agree that the company budget practices do not contradict with literature. It is concluded that to ensure an effective an efficient budget and budgetary control system identifying and mitigating limiting factors to budgets are the most relevant.
\end{abstract}

Keywords: Budgeting, budgetary control, timber industry, logs and lumber limited

\section{Introduction}

Budgeting is a technique which is widely used in business as a tool of management and it involves all levels of management. Budgeting aids management in its functions of planning and control. Planning is the basic function of the management that determines the course of action taken by estimating the degree of probable success in its effort to achieve its aim. Mockler (1972, p.2), defines control as "a systematic effort to set performance standards with planning objectives, to design information feedback systems, to compare actual performance with these predetermined standards, to determine whether there are any deviations and to measure their significance, and to take any action required to ensure that all corporate resources are being used in the most effective and efficient way possible in achieving corporate objectives". The control process involves the following steps:

(a) Establishment of standards and methods for measuring performance;

(b) Measurement of the performance against these standards; (c) Correcting variations from standards and plans.

Standards are performance criteria that signal management whether its objectives are executed according to plan. Budgeting is integral to the planning and control process which determines the future direction of the organisation. Logs \& Lumber Limited, a private limited liability company was chosen for this study to examine the nature and extend of implementation of budgetary control system in the timber industry in Ghana. Specically, the study seeks to achieve the following objectives:

1. To assess the types of budgets that are prepared by Logs and Lumber Limited

2. To examine whether budgeting and budgetary control practices conform to the best practices.

\section{Hypothesis}

$\mathrm{H}_{0}$ : There is no significant difference in the budgeting and budgetary control practices in Logs and Lumber Limited and what is practised in literature. 
$\mathrm{H}_{1}$ : There is significant difference in the budgeting and budgetary control practices in Logs and Lumber Limited and what is practised in literature.

This study examines the nature and extent of implementation or use of budgetary control system in the planning and control functions in $\operatorname{Logs} \&$ Lumber Limited in an attempt to achieve business success.

\section{Literature Review}

\subsection{Conceptual framework}

According to Johnson (1996) most organizations started using budgets in their operations since 1960 however, in the 1970s the concentration was on financial management rather than performance control. Companies which started using budget and budgetary control system in the 1980s and 1990s had problem such as effective customer relation because their focus was solely on sales rather than customer service. With time their attention shifted from sale to industrial capitalism.

\subsubsection{Reasons for budgeting in organisations}

Various researchers have defined budget in different ways. A budget is an expression of the money inflow and outflow that reveals whether the current operating goal will meet the organization's financial objectives (Ahmed, Suleiman and Alwi, 2003; Atkinson, 2004). Budgeting serves as a detail plan that determines future inflows and outflows usually one year (Noreen,2003; Weetman,2006;Wicks,2010;Gyasi,1992; CIMA). These definitions show that budget is prepared in advance and serves a plan quantified in financial terms to be achieved within a specified period of time.

\subsubsection{Best practices of budgeting and budgetary control practices}

Budgeting is a predictive model of an organization's activity, quantitatively expressed, for a set time period (Horngren, Stratton, Sutton, and Teall, 2004; Proctor et al, 2006; Bradford,2010). Budget process is a method of translating the corporate objective of the organisation into action. It serves as a strategic plan that guides the long term goal the company. It it must be approved by management in advanced. The conceptual overview of a budget process is shown below:

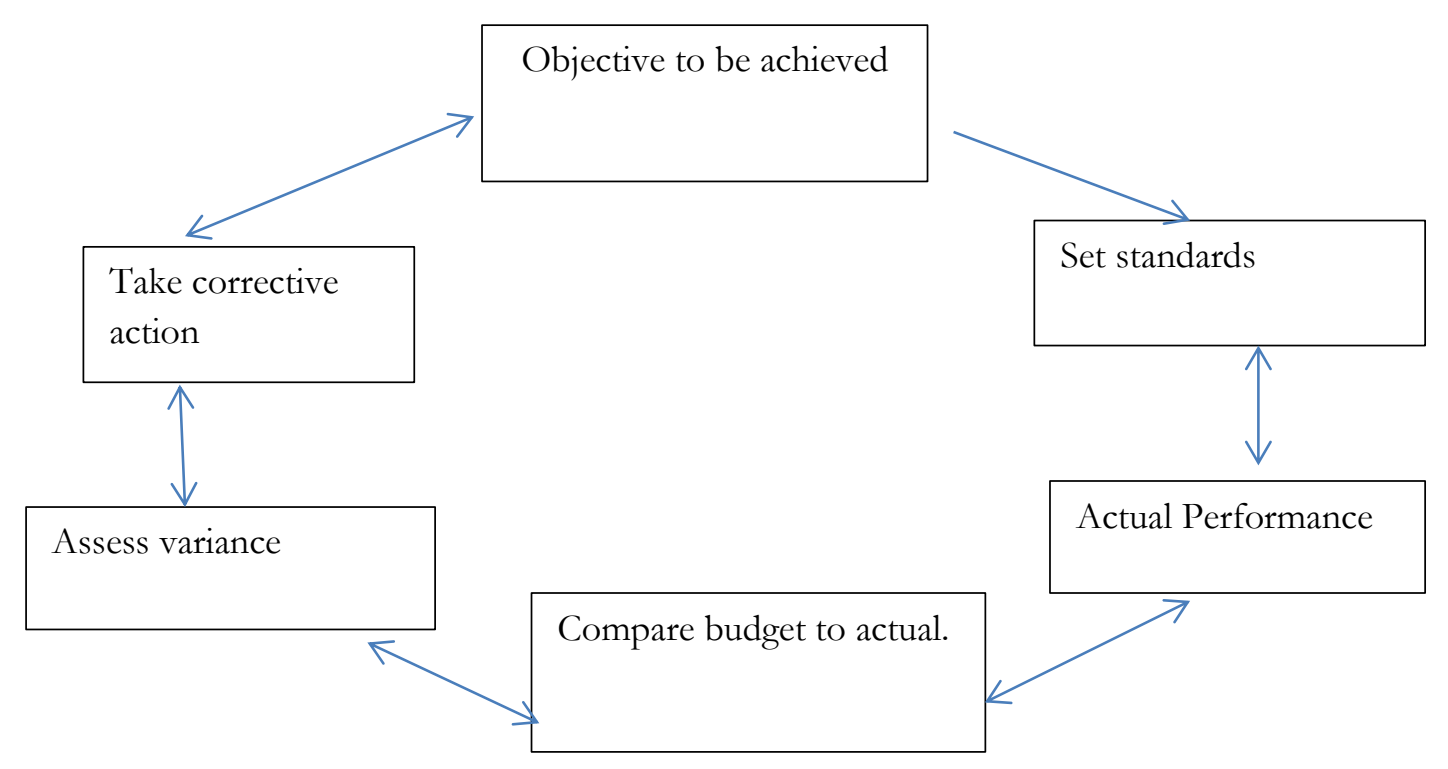

Fig. 1: Conceptual Framework-Budget and Budgetary Control

The conceptual framework (Fig. 1)has been adopted for this study. The study is posits on the conception that, an organization programs are tailored towards their budget. A program must show clearly what an organization must do. The goal also states the channel by which an organization want achieve this aim. The objectives must show how the goals would be achieved by the organization whilst 
performance measurement assess whether the objectives by large the general goals are achieved or not. Budgetary control helps businesses to measure plan activities against standards and variance reported (Drury, 2005; Kpedor, 2012, Lucey, 2008). It presupposes that a business must have a plan with clear sets of objectives. It helps managers to assess whethet performance targets are achieved. It also keep expenditure within limits and deviations are noted for corrective action. These two processes are very important to every organisation. It helps to safeguard its assets and liabilities.

\subsubsection{Problem of budgeting}

Generally, budget are prepared based on past records instead of future records. This results in a problem of predicting accurately for the future. This is known as the quantitative problem of budgeting whilst qualitative problem is as a result of predicting human behavior in budgeting.

\subsection{The budgetary control process}

Arthur Andersen (2000) in his effort to examine budget processes in companies. He alluded to the fact that companies stand at a great advantage when it prepares budget because it helps in improvement of its activities and coordination of its effort towards the achievement of its goals. Lucey, (2003) also was of the view that, for an organisation to have best practice in its budget preparation it must have a long term objectives, detailed organizational structure, quick reporting system, identification of the principal budget factor, and the participation of all employees, formation of a budget committee and the motivation employees and flexibility of the budgeting and budgetary control system. Robinson (2007) identified two stages of the budgeting process as budget and budgetary control. Budgeting and budgetary control are management functions whilst budget is planning function which focuses on the future, budgetary control on the other hand examine the plans executed and check for any variations from these plans. This deals with action that is taken to ensure that actual performance of budgeted activity conforms to pre-determined plans. In order words, budgetary control deals with regulating the activity of the business to follow the pattern that had previously been planned in the budget. CIMA terminology defines the term budgetary control as "the establishment of budgets relating the responsibilities of executives to the requirements of a policy and the continuous comparison of actual with budgeted results, either to secure by individual action the objective of that policy or to provide a basis for its revision".

\subsection{Empirical review}

A lot of research has been conducted on this topic, budget and budgetary control. Whilst some focused on the public sector, others concentrated on the private sector. Others looked at it as an annual exercise that has to be undertaken by organisations. Owusu-Mainu and Yeboah (2016), in their work at Garden City University College reviewed the nature and scope of budgeting and budgetary control practices centered on preparing budget annually which conform to their budget manual with regular review before implementation, and control. In a similar work by Trimisiu Tunji (2013) in Nigeria Manufacturing companies, discovered worker participation in the budgeting process in the company is high and employee motivation is very high which moves the company to greater heights. He concluded that the company has a dedicated work force.

Abdullahi et.al., (2015), in his work at Tahir Guest House in Nigeria Kano stated among other things that top level management of Tahir Guest Palace should maintain appropriate standard on budget administration, preparation, and budget process. Also, staff of various cadres at Tahir Guest Palace should also be allowed to participate in the budget target setting and process to further enhance its organizational performance. Furthermore, Badu (2011) on the subject on an investigation of budgeting and budgetary control at Ernest Chemist, the responses he collated from respondents indicated that budgets prepared at the pharmacy were normally prepared for a period of one year. In practice, the year is broken down in twelve (monthly) control periods, the pharmacy has four (4) departments which are sales, production, finance and administration and each of these is controlled by a manager. According to Badu (2011), the preparation of budgets is done by a budget committee which is headed by the budget director, who controls and coordinates the process of the budget. Before the commencement of the budget the committee follows some stages and they are discussed below.

First of all is the principal budget factor determines which budget to be prepared first or last. Usually it is the sale volume that is said to be prepared first and it is based on the available sale forecast. After this budget all other subsidiary budgets are then prepared and link to it. The Sale 
budget is the first component of master budget; this is because sales affect all the parts of the master budget. On the approaches to budgeting it was revealed that Ernest Chemist Limited in Accra, Ghana used incremental budget approach. The explanation given for using this budget approach indicated that it assisted management to look into the future and also help to make provision towards market conditions, inflation and unforeseeable negative economy changes and assist also management to attain desired objective. Regarding budgetary control practices at Ernest Chemist, Badu (2011) found that it normally involved frequent reporting of actual achievement and cost compared with budgeted achievement followed by management review, and any necessary corrective action taken.

With regard to what extent budgeting control has been used by the company, it was observed from the response that management usually prepares a variance report statement to compare the expected income and expenditure with the actual income and expenditure to show whether variance revealed are favourable or adverse. Management does this to be able to prepare better preventive measures towards any such future occurrence.

More research have to be carried out to enable businesses measure the quality of budgeting systems actually practiced in various organisations with lack of attention to Timber companies. This study focuses on the features of good budgeting systems inTimber company.

\section{Methodology}

The data for this study were obtained from both primary and secondary source. The primary data included the information gathered through questionnaires and structured interview. Convenient sampling method was used to select the respondents. The respondents were heads of Finance, Administration, Production and sales and marketing departments and thirteen (13) other staff members. This individuals were selected because of their active involment in the budgeting activities of the company. The questionnaire for the respondents was a five (5) likert scale item. The respondents were visited at their work place by the researchers within the Kumasi Metropolis of Ghana and it took them two weeks to respond to the administered questionnaire, and the retrieval rate was $100 \%$. A structured Face to face interview was conducted with the seventeen (17) repondents to clarify some information provided. The secondary data included budget reports and budget manual from 2011-2015 on the subject that have already been prepared and made available. SPSS was used for the analyses which enabled us give our results.

\section{Results and Discussions}

The study revealed that budget planning takes place at the various departments of the company and all these are coordinated by the Accounting Department. The main budgets prepared in the company are Sales budget, Production Budget, Material Usage Budget, Purchases Budget, Direct Labour Budget, Production Overhead Budget, Selling and Distribution Expense Budget,General and Administration Expense Budget. All the 17 respondents agree that the company prepares the above budgets. However, two of the most common budgets usually prepared by organisations namely cash budgets and capital expenditure budget are not prepared by the company. The company not preparing the Capital budget constitute an improper financial management practice. The firm's cash position may be disrupted when it decides to finance any project from funds not previously planned for.

This is in contradiction with the assertion of (Ahmed, Suleiman and Alwi, 2003; Atkinson, 2004, Weetman, 2006) that a budget is an expression of the money inflow and outflow that reveals whether the current operating goal will meet the organization's financial objectives has been defeated. Logs and Lumber Limited preparing some budgets implies that it will be able to predict the output of some of its operationg activities but not all of its cash inflow and cash outflow for the period however, the company's action it is line with (Noreen,2003; | Weetman,2006; | Wicks,2010; | Gyasi,1 992) that the company has detail plan in place that determines future of the company.

From fig. 2 below, the sales of the company in 2011 was 62,439 Ghana cedis as against the budget for period of 57,600 Ghana cedis with a favourable variance of 4,839 Ghana cedis. In 2012, the sales for the company was 67,864 Ghana Cedis as against the budget of 71,452 Ghana Cedis however, the variance for the period was adverse of 3,588 Ghana cedis. In 2013, the sales for the period was 262,669 Ghana cedis as against a buget of 199,740 Ghana ceis with a favourable variance of 62,929 Ghana cedis. In 2014, the sales of the company 624,457 Ghana cedis as against 526,360 Ghana cedis with a favourable variance of 95,097 Ghana cedis. It coul be seen that the company's sales was favourable throughout the period of study. This implies that the company is doing well in its production. However, the cost of 
sales of the period had adverse variance throughout the period.

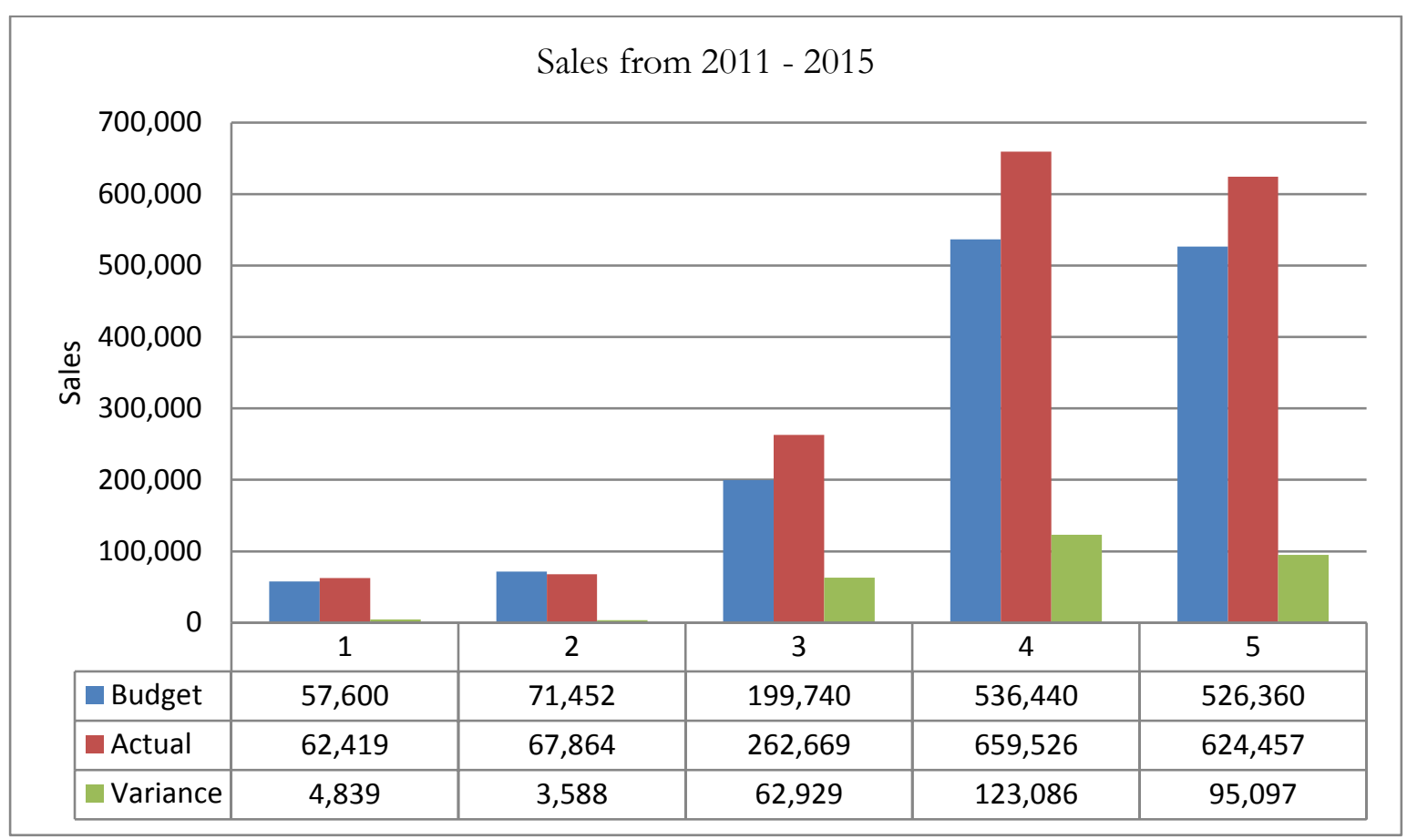

Fig. 2: Budgeted Sales, actual and variance from 2011- 2015.

From figure 3 , in 2011, the cost of sales was 51,163 Ghana cedis against a budget of 45,870 Ghana cedis with a variance 5,293 Ghana cedis. In 2012, the cost of sales 59,367 against a budget of 49,292 Ghana cedis with a variance of 10,085 Ghana cedis. In 2013, the cost of sale was 195,423 Ghana cedis as against projected value of 160,276 Ghana cedis with a variance of 3,5147 variance. In 2014 , the cost of sales
526,453 Ghana cedis as against a budget of 309,781 Ghana cedis with a variance of 216, 672 Ghana cedis. In 2015 , the cost of sales was 650,879 Ghana cedis as against 440,548 Ghana cedis with a variance 210,331 Ghana cedis. This clear shows that the company's cost of production must be critically looked at to reduce production cost.

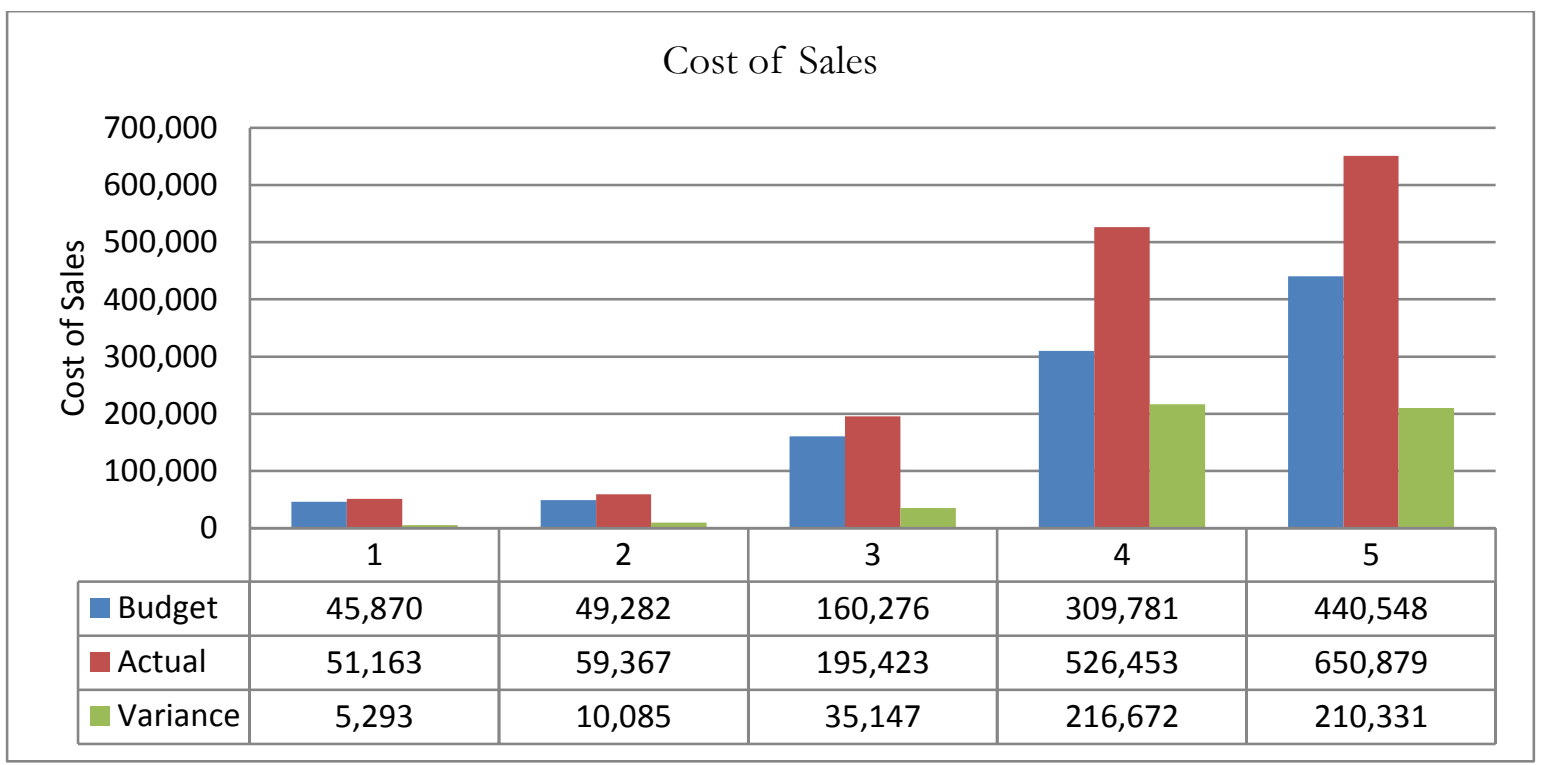

Fig. 3: Budgeted cost of sales, actual and variance from 2011- 2015. 
Table 1

Sample statistics of respondents.

One-Sample Statistics

\begin{tabular}{lllll}
\hline & $\mathrm{N}$ & Mean & Std. Deviation & Std. Error Mean \\
\hline $\begin{array}{l}\text { Budget Practices in Logs and Lumber } \\
\text { Limited }\end{array}$ & 17 & 4.6471 & .60634 & .14706 \\
\hline
\end{tabular}

From table 1, with a total number of 17 respondents selected from Logs and Lumber Limited, using a likert scale of 5, a mean of 4.6471 and standard deviation of 0.60634 strongly agree the company prepares budget. This shows that Log and Lumber Limited has a an effective budget committee in place which draws its budget and ensure its implementation.

Table 2

Sample Test of the respondents.

One-Sample Test

\begin{tabular}{|c|c|c|c|c|c|c|}
\hline & \multicolumn{6}{|c|}{ Test Value $=0$} \\
\hline & \multirow[b]{2}{*}{$\mathrm{t}$} & \multirow[b]{2}{*}{ df } & \multirow{2}{*}{$\begin{array}{l}\text { Sig. }(2- \\
\text { tailed })\end{array}$} & \multirow{2}{*}{$\begin{array}{l}\text { Mean } \\
\text { Difference }\end{array}$} & \multicolumn{2}{|c|}{$95 \%$ Confidence Interval of the Difference } \\
\hline & & & & & Lower & Upper \\
\hline $\begin{array}{l}\text { Budget Practices in Logs and } \\
\text { Lumber Limited }\end{array}$ & 31.600 & 16 & .000 & 4.64706 & 4.3353 & 4.9588 \\
\hline
\end{tabular}

From table 2 above, the mean difference between the groups is 4.64706 with an upper value of 4.9588 and a lower value of 4.3353 . The analysis further shows that $p$ value of 0.00 is less than the apha value of 0.05 , this means that there is no significance difference between the budget prepared by Logs and Lumber Limited and that stated in literature. This leads to the acceptance of the null hypothesis which states that:

$\mathrm{H}_{\mathrm{o}}$ : There is no significant difference in the budget and budgetary control practices in Logs and Lumber Limited and what is practised in literature.

Therefore it can be concluded that the company's budget process is in line with literature. This finding is in line with the finding of Abdullahi et.al., (2015) and Trimisiu Tunji (2013) that management of the studied organisations have budgeting process in place which helps workers to give off their best.

\section{Conclusions}

The study revealed that Logs \& Lumber Limited prepares budgets as tool for management decision making. Generally, the firm has a good budget and budgetary control system in place. It is recommended that the system could be improved if the company were to prepare the cash and capital expenditure budgets. It could be realised that at anytime the company incurres higher capital expenditure financial position goes to negative and it has to borrow to finance such activities. This unfortunate situation could have been averted if adequate provision is made for the fixed asset. Also, the company should educate non-financial managers on budget targets. Ghanaian managers and for that matter managers in general need to pay particular attention to their budget and budgetary control systems to increase productivity and efficiency and ensure that organisational goal attainment. However, this study was confined to Logs and Lumber Limited a timber company in Kumasi, Ghana. Therefore similar work can be done elsewhere to assess the types of budget prepared there as well.

\section{References}

Abdullahi, S. R.,et. al., (2015), The role of budget and budgetary control on organisational performance: A case study of Tahir Guest House, Kano state, Nigeria, International Journal of Innovative Research in Information Security (IJIRIS) ISSN: 2349-7017(O) Issue 2, Volume 4 (April 2015)

Ahmad, N. N. N., Suleiman, N., and Alwi, N. M. (2003). Are budgets useful? A survey of Malaysian companies. Managerial Auditing Journal, 18 (9), 717-724. 
Andersen, A. (2000) Best Practices Developing budget Article

Asamoah, F. O. (2011) Budgeting and budgetary control practices of Koforidua Polytechnic .

CIMA Terminology, www.cimaglobal.com.

Drury, (2005) Management and cost accounting 5th Edition Thomson Publishers.

Fuior, E; and Gutan, V; (2015), The Budgeting based on the Performance:ConceptualFramework and Implementation Details, Economy Transdisciplinarity Cognition.

Gyasi, K., (1992). "Management Accounting", Kwabotwe Hill Publishers, Accra, $1^{\text {st }}$ ed, p.48.

Horngren, C. T., Stratton, G. L., Sutton, W. O., and Teall, H. D. (2004). Management Accounting. (4th Ed.). Toronto: Prentice Hall Publishers.

Kpedor, G. (2012). Budgeting, Budgetary Control and Performance Evaluation: A Case Study of Alterain Service Group. A Published Thesis Commonwealth Executive Master of Business Administration, Kwame Nkrumah University of Science and Technology.

Lucey, T. (1993) costing (4th ed) Braye Road: Guernsey co. Ltd.

Lucey, T. (2003) Management Accounting 5th Edition. Book Power, London.

Mockler, R. J., (1972). "The Management Control Process" Englewood Cliffs, N.J. Prentice Hall, p.2
Noreen, (2003) Management Accounting 10th Edition McGrow Hill.

Owusu-Mainu, R and Yeboah, E, (2016), Budgeting and Budgetary Control Practices Of Private Universities in Ghana: A Case of Garden City University College. Researchjournali’s Journal of Accounting Vol. 4 | No. 1 May | 2016.

Proctor, (2006) Management Accounting for Business Decision 2nd Edition Prentice Hall.

Proctor, (2010) Blending Financial Models 2nd Edition Wiley Finance.

Saunder, et al (2009) Research Methods for Business Students 5th Edition Prentice Hall.

Shah, Anwar (ed.) (2007), Budgeting and Budgetary Institutions, the World Bank, Washington DC.

Trimisiu Tunji, S., (2013), The Impact Of Budgeting And Budgetary Control On The Performance Of Manufacturing Company In Nigeria. Journal of Business Management \& Social Sciences Research (JBM\&SSR), Volume 2, No.12,

Weetman (2006) Management Accounting 5th Edition Prentice Hall. 